\section{Enkel grunnbok om avhengighet}

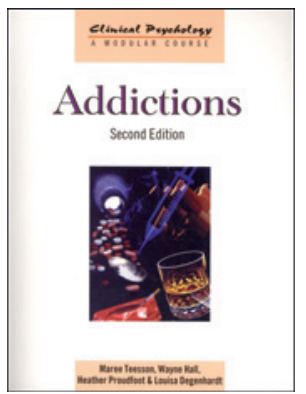

Maree Teesson, Wayne Hall,

Heather Proudfoot et al.

\section{Addictions}

2. utg. 158 s, tab. Hove: Psychology Press,

2012. Pris GBP 18

ISBN 978-0-415-58300-8

Siden jeg anmeldte førsteutgaven i Tidsskriftet i 2003 (1) har rusog avhengighetsfeltet endret seg mye. Vi har fått en stor tilflyt av ny kunnskap både med hensyn til epidemiologi, biologi, nye behandlingsmetoder og rusmidler. Dette gjenspeiler seg ikke i denne andreutgaven av grunnboken. Den er nesten side for side lik førsteutgaven, bortsett fra at man har ryddet litt i noen kapitler, kommet med noen nye referanser innen epidemiologi og lagt på et underkapittel om kognitiv atferdsterapi ved cannabismisbruk. Man har også inkludert en fjerde medforfatter, antagelig den som har stått for de små endringene som har funnet sted. I mine øyne strekker forfatterne grunnlaget for en ny utgave til det ytterste. Kanskje det er forlaget som har presset på? Det ville i så fall tjene forfatterne til ære!

Dette gjør ikke at jeg ikke står ved det jeg sa om førsteutgaven den gang. Det er en god grunnbok om rus og avhengighet for utdanningen i klinisk psykologi, men kan godt leses av folk innen andre profesjoner. Forfatterne innleder med fire generelle kapitler om den teoretiske forståelsen av avhengighet. Deretter gjennomgår de alkohol, nikotin, cannabis, opiater og sentralstimulerende midler i egne kapitler. Misbruk av benzodiazepiner eller andre legemidler med misbrukspotensial er ikke viet plass. De avslutter med en fyldig og god referanseliste, forslag til videre lesing, forfatterregister (som er nytt, men knapt nok nødvendig) og et godt stikkordregister.

Når man skal gi en innføring til rus- og avhengighetsfeltet tilpasset formatet som kan brukes i grunnutdanning i psykologi, må man være knapp, og det er ting som nødvendigvis er utelatt, men boken er godt og lettfattelig skrevet og tilbyr leseren det viktigste innen feltet.

Jeg anbefaler fremdeles boken, men har man førsteutgaven, trenger man ikke å kjøpe denne. De som derimot ikke har førsteutgaven, kan glede seg over at andreutgaven ti år senere bare koster litt over halvparten av førsteutgaven!

\section{Jørgen G. Bramness}

Senter for rus og avhengighetsforskning

Universitetet i Oslo

\section{Litteratur}

1. Bramness JG. Enkel grunnbok om avhengighetens grunnlag og behandling. Anmeldelse av: Teeson M, Degenhardt L, Hall W. Addictions. Tidsskr Nor Lægeforen 2003; 123: 76 .

\section{Kortfattet og utfyllende om dagkirurgi}

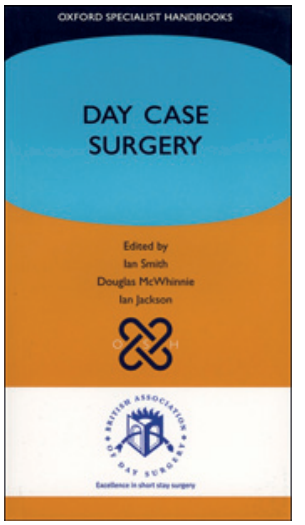

\author{
Ian Smith, Douglas McWhinnie.
}

lan Jackson, red.

Day case surgery

414 s, tab, ill. Oxford: Oxford University Press, 2011. Pris GBP 40

ISBN 978-0-19-958433-8

Boken kommer ut i serien Oxford Specialist Handbooks og er nettopp det - en håndbok. Den er redigert av noen av de mest erfarne dagkirurgiske kapasitetene i Storbritannia: Douglas McWhinnie, som er karkirurg og generell kirurg, i tillegg til anestesiologene Ian Smith og Ian Jackson. Sistnevnte er også kommende president i International Association of Ambulatory Surgery (IAAS). Til sammen 37 fagfolk fra hele Europa bidrar.

Dagkirurgi er ikke en medisinsk, men en logistisk spesialitet. Vi vet også fra vår egen hverdag at de som har fått til en velfungerende dagkirurgisk enhet, er de som har skjønt at denne spesialiteten er mer enn vanlig avhengig av samhandling mellom fagene anestesiologi og kirurgi og mellom leger og sykepleiere. Dagkirurgi er teamarbeid, og det europeiske målet er at $75 \%$ av all elektiv kirurgi skal gjøres dagkirurgisk. Denne boken er den beste jeg hittil har lest om temaet. Den gir virkelig nyttig faglig grunnlag for at dette målet skal nås.

Boken er delt i 20 kapitler. Bidragsyterne tar først for seg historiske og organisatoriske utviklinger. Så følger en del om anestesiformer og anestesi for ulike pasientgrupper i dagkirurgien, en del om de ulike kirurgiske inngrepene og til slutt en del om sykepleie, pasientsikkerhet, forskning og undervisning. Kapitlene er utformet likt, med korte punktvise momenter som inneholder imponerende mye fagstoff på de 414 små sidene.

Referanser, stikkordregister og ordforklaringer er gode og nyttige. Formen er velegnet til å få rask oversikt over viktige momenter i de ulike fasene av dagkirurgisk virksomhet, kortfattet og lettlest, likevel med tilstrekkelig tekst.

Innholdet er stort og faglig svært godt oppdatert. Samtidig er det «kirurgi for anestesiologer og anestesiologi for kirurger», noe jeg mener er akkurat det som behøves for å forstå og respektere hverandres fagfelt. Behovet for å bruke dagkirurgien i forskning og undervisning er også utdypet og vektlagt, og dette har lenge vært viktige temaer i International Association of Ambulatory Surgery.

Jeg kan ikke annet enn å anbefale dette innholdsrike, oppdaterte og faglig gode oppslagsverket $i$ håndbokformat.

\section{Inge Glambek}

Kirurgisk avdeling

Haraldsplass Diakonale sykehus

Bergen 